\title{
変調分光法によるステンレス鋼の不働態皮膜の分析 ${ }^{*}$
}

\author{
原信 義**, 杉 本 克 久** \\ **東北大学工学部金属工学科.
}

\author{
Analyses of the Passive Films on Stainless Steels \\ by Modulation Spectroscopy* \\ Nobuyoshi Hara** and Katsuhisa Sugimoto** \\ **Department of Metallurgy, Faculty of Engineering, Tohoku University
}

\begin{abstract}
In order to gain a better understanding of the change in the chemical composition of surface films on stainless steels as a function of the alloy composition or electrode potential, surface analyses by modulation spectroscopy were performed on a series of $\mathrm{Fe}-\mathrm{Cr}$ alloys $(5$ to $70 \% \mathrm{Cr}$ ), $20 \mathrm{Cr}-$ $25 \mathrm{Ni}$ stainless steel and pure metals constituting these alloys ( $\mathrm{Fe}, \mathrm{Cr}$ and $\mathrm{Ni}$ ) at various anodic potentials in $1 \mathrm{M}-\mathrm{Na}_{2} \mathrm{SO}_{4}$ solution ( $\mathrm{pH} 2.0$ ). On the basis of photon energies and intensities of characteristic peaks in the modulated reflection spectra, the kinds and quantities of constituent species of the films were examined. It was found that a sharp and substantial increase in $\mathrm{Cr}^{3+}$ ions in the film of $\mathrm{Fe}-\mathrm{Cr}$ alloy occurs at potentials in the passivity region with increasing $\mathrm{Cr}$ content of the alloy up to $20 \%$. The film composition continuously changes with electrode potential, e. g., the film formed on $\mathrm{Fe}-20 \mathrm{Cr}$ alloy at a potential in the passivity region is mainly composed of chromic oxides and in the secondary passivity region is of ferric oxides. The passive film on $20 \mathrm{Cr}-$ $25 \mathrm{Ni}$ stainless steel has nearly the same composition as that on $\mathrm{Fe}-20 \mathrm{Cr}$ alloy except for containing a small amount of nickel oxides.
\end{abstract}

\section{1. 緒 言}

$12 \%$ 以上の $\mathrm{Cr}$ を含む $\mathrm{Fe}-\mathrm{Cr}$ 合金が不働態化しやす くすぐれた耐食性を示すことから，この合金の不働態皮 膜の構造や組成は電子線回折 ${ }^{1}$, , 軟 $\mathrm{X}$ 線分光法 $\left.{ }^{2}\right), \mathrm{X}$ 線

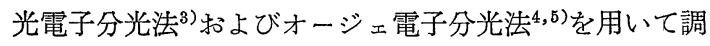
ベられている。これらの研究結果はいずれも合金の $\mathrm{Cr}$ 含有量の増加とともに不働態皮膜の構造と組成に変化が 生ずることを示しているが，これらの研究はすべて不働 態化処理ののら空気中に取り出された皮膜について行わ れたものであり，水溶液中で生成したままの状態の皮膜 の構造や組成についてはまだ推測の域を出ない。

そのため本研究では, 水溶液中で不動態化したままの 状態で，一連の $\mathrm{Fe}-\mathrm{Cr}$ 合金および 20Cr-25Ni オース テナイトステンレス鋼の表面を変調分光法を用いて分析 し，不働態皮膜の化学組成に及ぼす皮膜形成電位および 合金組成の影響を明らかにすることを目的とした。

変調分光法は半導体のバンド構造の研究のために開発

* 1978 年 5 月, 本協会 '78 春期学術講演大会に一部 発表

** T980 仙台市荒巻字青葉 (Aza-Aoba, Aramaki, Sendai, 980, Japan)
された方法であるが，最近，水溶液中での金属電極の表 面現象の研究にも応用されるようになっだ6)。この方法 に上れば電極上に形成される極めて薄い表面層の化学組 成も水溶液中に存在するままの状態で分析することがで きるので, この方法は不働態皮膜の研究手段としても有 力な方法である。しかし，この分野に打ける応用例はま だ少なく，Paatsch らによる $\mathrm{Ni}^{7}{ }^{7,8}, \mathrm{Fe}^{9)}, \mathrm{Ti}^{10)}$ および $\mathrm{Cu}^{11)}$ の研究, Heusler らによる Ni の研究 ${ }^{12)}$ 打よび Rozenfel'd らによる Fe の研究 ${ }^{13,14)}$ があるだけである。

\section{2. 実験方法}

試料としては一連の $\mathrm{Fe}-\mathrm{Cr}$ 合金 $(5 \sim 70 \% \mathrm{Cr}), 20 \mathrm{Cr}-$ $25 \mathrm{Ni}$ ステンレス鋼およびこれらの合金の構成成分の純 金属 $(\mathrm{Fe}, \mathrm{Cr}$ および $\mathrm{Ni})$ を用いた。試料として用いた純 金属拉よび合金の化学組成々熱処理条件を表 1 亿示す。 試料の大きさは寸べて $30^{1} \times 20^{\mathrm{w}} \times 2^{\mathrm{t}}(\mathrm{mm})$ である。試 料の表面をエメリ一紙 6/0 番まで研磨, 酸化クロム羽布 研磨, ダイヤモンドペースト研磨の順で鏡面に仕上げた 後, 石油エーテルとエチルアルコール中で超音波洗浄し た。電極面積として試料表面に $2 \mathrm{~cm}^{2}$ をとり, あとの部 分はエポキシ樹脂で被覆した。 
Table 1. Chemical composition (wt \%) and heat-treatment conditions of the specimens.

\begin{tabular}{|c|c|c|c|c|c|c|c|c|c|c|}
\hline Specimen & Cr & $\mathrm{Ni}$ & C & Si & $\mathbf{P}$ & $S$ & Mo & $\mathrm{Cu}$ & Mn & Heat-treatment \\
\hline Pure Iron & . & & 0.003 & 0.006 & 0.002 & 0.004 & 0.008 & 0.011 & & As Cast \\
\hline Pure Chromium & 99.29 & & 0.020 & 0.008 & 0.001 & 0.024 & & 0.0005 & & $820^{\circ} \mathrm{C}, \quad 5 \mathrm{~min} \rightarrow \mathrm{AC}$ \\
\hline Pure Nickel & & 99.96 & 0.002 & .0 .008 & & & $<0.001$ & 0.002 & & $1000^{\circ} \mathrm{C}, 30 \mathrm{~min} \rightarrow W Q$ \\
\hline $\mathrm{Fe}-5 \mathrm{Cr}$ & 5.31 & $<0.01$ & 0.001 & 0.01 & 0.003 & 0.007 & 0.01 & 0.01 & & $830^{\circ} \mathrm{C}, \quad 5 \mathrm{~min} \rightarrow W Q$ \\
\hline Fe-10Cr & 10.70 & $<0.01$ & 0.001 & 0.01 & 0.002 & 0.008 & 0.01 & 0.01 & & $830^{\circ} \mathrm{C}, \quad 5 \mathrm{~min} \rightarrow \mathrm{WQ}$ \\
\hline $\mathrm{Fe}-15 \mathrm{Cr}$ & 15.91 & $<0.01$ & 0.001 & 0.01 & 0.002 & 0.009 & 0.01 & 0.01 & & $830^{\circ} \mathrm{C}, \quad 5 \mathrm{~min} \rightarrow W Q$ \\
\hline $\mathrm{Fe}-20 \mathrm{Cr}$ & 21.20 & $<0.01$ & 0.001 & 0.01 & 0.002 & 0.010 & 0.01 & 0.01 & & $830^{\circ} \mathrm{C}, \quad 5 \mathrm{~min} \rightarrow W Q$ \\
\hline $\mathrm{Fe}-30 \mathrm{Cr}$ & 32.30 & 0.01 & 0.001 & 0.03 & 0.002 & 0.012 & 0.01 & 0.01 & & $1100^{\circ} \mathrm{C}, 60 \mathrm{~min} \rightarrow$ WQ \\
\hline $\mathrm{Fe}-40 \mathrm{Cr}$ & 42.31 & 0.18 & 0.002 & 0.42 & 0.016 & 0.019 & 0.01 & 0.01 & & $1100^{\circ} \mathrm{C}, 60 \mathrm{~min} \rightarrow$ WQ \\
\hline $\mathrm{Fe}-60 \mathrm{Cr}$ & 58.20 & 0.16 & 0.002 & 0.45 & 0.011 & 0.021 & 0.01 & 0.01 & & $1100^{\circ} \mathrm{C}, 60 \mathrm{~min} \rightarrow W Q$ \\
\hline $\mathrm{Fe}-70 \mathrm{Cr}$ & 72.10 & 0.13 & 0.001 & 0.48 & 0.010 & 0.024 & 0.01 & 0.01 & & $1100^{\circ} \mathrm{C}, 60 \mathrm{~min} \rightarrow W Q$ \\
\hline $\mathrm{Fe}-20 \mathrm{Cr}-25 \mathrm{NI}$ & 20.06 & 25.58 & 0.053 & 0.54 & 0.009 & 0.010 & & & 1.53 & $1050^{\circ} \mathrm{C}, 60 \mathrm{~min} \rightarrow$ WQ \\
\hline
\end{tabular}

電解液は, 少量の $\mathrm{H}_{2} \mathrm{SO}_{4}$ 溶液を添加することによっ て pHを 2.0 に調整した $1 \mathrm{M}-\mathrm{Na}_{2} \mathrm{SO}_{4}$ 溶液を使用した。 溶液は使用前に 2 時間以上リザーバ中で精製 $\mathrm{N}_{2}$ ガスを 吹き込むことによって脱気した。

試料はポテンショスタットを用いて電解液中で定電位 的にアノード分極した。活性溶解域に括ける試料表面の エッチングを避けるために，各試料の不働態化電位より も約 $200 \mathrm{mV}$ 貴な電位から測定を開始した。電位は 50 $\mathrm{mV}$ 間隔でアノード方向に变化させ, 各設定電位には 30 分間保持した。各電位における 30 分後の電流值と, 特定の電位に护ける変調反射スペクトルを測定した。す ベての測定は $20^{\circ} \mathrm{C} て ゙$ 行った。照合電極としては飽和カ ロメル電極 (SCE) を用い, 本論文中の電位はすべて SCE 基準で示す。

変調反射スペクトルを測定するために用いた装置のブ ロック図を図 1 に示す。光源 (LS) としては $150 \mathrm{~W}$ のキ セノンランプを用いた。キセノンランプからの光はモノ クロメータ $(\mathrm{MC})$ によって単色光となり, 周波数 $f_{\mathrm{c}}$ (=340 Hz) で動作させたライトチョッパ (C) を通過し たのち, 光学セル (OC) 中の試料電極 (WE) の表面に 入射角 $60.00^{\circ}$ で入射した。光学セルは入射角を $60.00^{\circ}$ に固定した $2 つ の$ 空を有するパイレックスガラス製であ り，空材として石英製のオプチカルパラレルを使用し た。試料電極の電位を変調するために，ファンクション ゼェネレータ (FG) を用いてポテンショスタット (PS) の設定電位に周波数 $f_{m}(=20 \mathrm{~Hz})$ の正弦波交流電圧を 重盢した。光電子増倍管 (PM) によって検出される反射 光強度は 2 台のロックイン増幅器で増幅した。基準周波

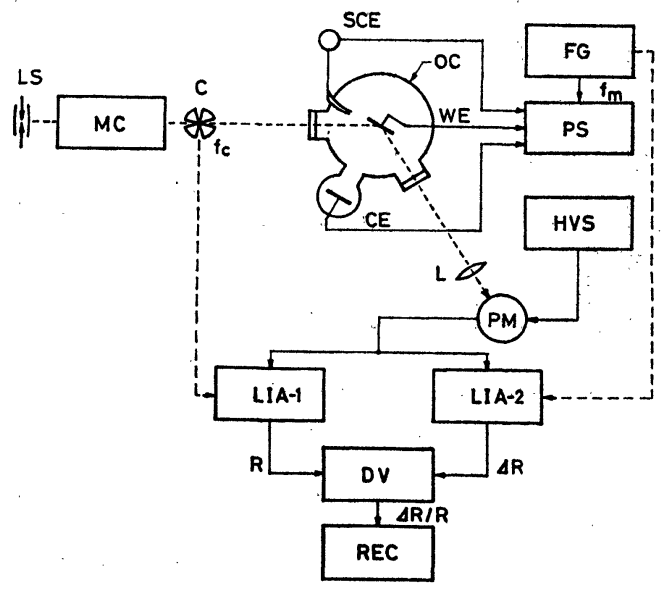

Fig. 1. Block diagram of the apparatus for modulation spectroscopy.

数 $f_{c}$ に同調するロックイン増幅器 (LIA-1) は測定電位 に掠惊定反射率 $R$ に比例する信号を， $f_{m}$ に同調す るロックイン 増幅器 (LIA-2) は電位の変調によって生 ずる反射率変化 $\Delta R$ に比例する信号を増幅した。2 台の ロックイン増幅器の出力はアナログ除算器 (DV) に入力 し, 除算器の出力 $\Delta R / R$ をレコーダ (REC) 上に記録し た。

変調反射スペクトルの測定は $1.6 \sim 5.9 \mathrm{eV}$ のエネルギ 範囲 (波長 $\lambda=210 \sim 800 \mathrm{~nm}$ ) で行った。電極電位の変 調振幅 $\Delta E$ は不働態域では $400 \mathrm{mV}_{\mathrm{p}-\mathrm{p}}$ 以下，過不働態 域では $100 \mathrm{mV}_{\mathrm{p}-\mathrm{p}}$ 以下とした。予備実験の結果, $\Delta E=$ $50 \sim 400 \mathrm{mV}_{\mathrm{p}-\mathrm{p}}$ の場合 $\Delta R / R$ と $\Delta E$ の間にほぼ直線的 
な関係が認められたので，得られたスペクトルはすべて $\Delta E=100 \mathrm{mV}_{\mathrm{p}-\mathrm{p}}$ で規格化して示し，、スペクトル強度を 比較できるようにした。

\section{3. 実験結果と考察}

\section{1 純 $\mathrm{Fe}$ の変調反射スペクトル}

$1 \mathrm{M}-\mathrm{Na}_{2} \mathrm{SO}_{4}$ (pH 2.0) 溶液中に护㑈 $\mathrm{Fe}$ のアノー ド分極曲線と変調反射スペクトルの電位による变化を図 2 (a) および (b) に示す。不働態化電位より約 $0.2 \mathrm{~V}$ 貴 な電位である $+0.40 \mathrm{~V}$ に抢けるスペクトルには $3.2 \mathrm{eV}$ に最大ピークが現われ，2.4拈よび $4.1 \mathrm{eV}$ に肩が認めら れる。 $+0.60 \mathrm{~V}$ から $+1.10 \mathrm{~V}$ までの電位で得られたス ペクトルはいずれも $3 \mathrm{eV}$ 付近に最大ピークを示すが, そのピークの位置は電位の上昇とともに低エネルギ側に 移動し，同時に高エネルギ側のスペクトル強度が低下す る。酸素発生電位より約 $0.1 \mathrm{~V}$ 卑な電位である $+1.30 \mathrm{~V}$ に淤けるスペクトルは $+1.10 \mathrm{~V}$ 以下の電位に淤けるス

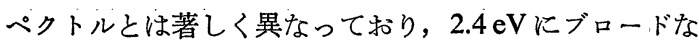
正のピーク， $3.4 \mathrm{eV}$ に負のピーク，そして $4.0 \mathrm{eV}$ に正 のピークが現われる。この電位におけるスペクトル強度 は全体的に高く，特に低エネルギ側に拄いてその傾向が 著しい。
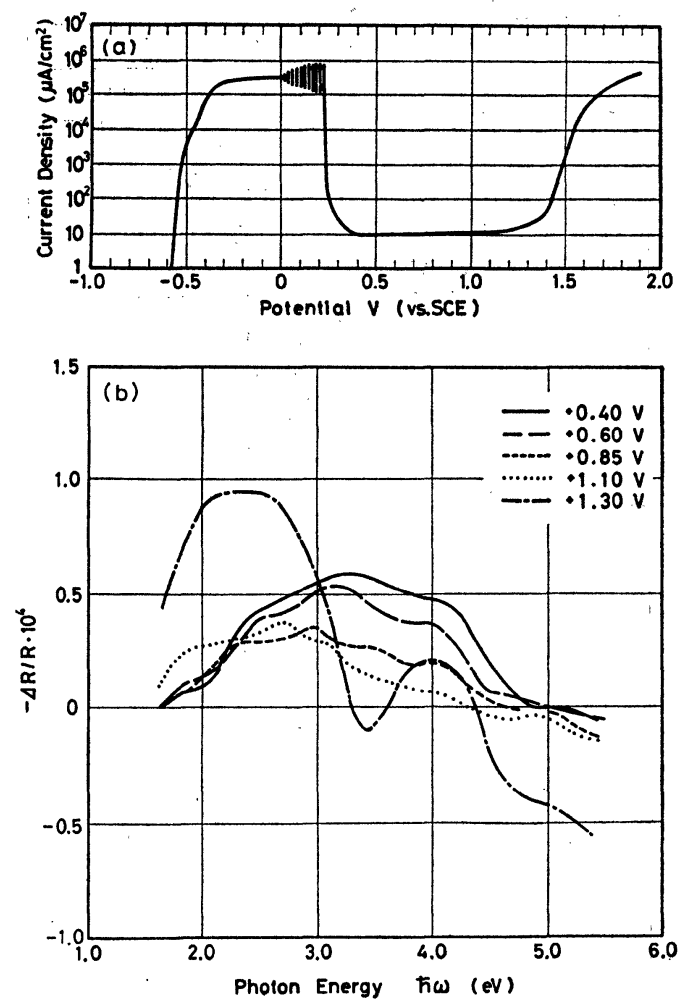

Fig. 2. Anodic polarization curve (a) and modulated reflection spectra (b) for iron in $1 \mathrm{M}-\mathrm{Na}_{2} \mathrm{SO}_{4}$ (pH 2.0).
不働態化した金属電極では金属素地のエレクトロリフ レクタンス効果 ${ }^{15,16) を}$ 無視することができるので，電位 の変調による反射率の変化は主として不働態皮膜の光学 定数の变調によって生ずると考えることがでさる17)。不 働態皮膜の光学定数は皮膜構成物質に固有の吸収が起こ るエネルギ值付近で著しく変化するので，そのような所 では電位の変調による光学定数の变調も大きく, 変調反 射スペクトルにピークなどの特徵的な变化を生ずる。乙 たがって，測定された变調反射スペクトルに現われるピ 一クの位置から皮膜構成物質を同定することができる。

これまでに報告されている $\mathrm{Fe}$ 化合物の吸収スペクト ルによれば， $\mathrm{Fe}^{2+}$ イオンを含む化合物は可視域では注 ぼ透明で特別な吸収帯を示さないが，紫外域に強い電荷 移動吸収带を有しており，その吸収端は約 $4.8 \mathrm{eV}$ にあ る ${ }^{18)}$ 。一方, $\mathrm{Fe}^{3+}$ イオンを含む酸化物は約 $3 \mathrm{eV}$ にピ 一クを生ずる強い電荷移動吸収帯を有しており，この吸 収は $2.4 \mathrm{eV}$ 付近から起こる ${ }^{18,20)} 。 \mathrm{Fe}^{2+}$ と $\mathrm{Fe}^{3+}$ イオン の吸収帯の位置はかなり異なっているので, 変調反射ス ペクトルに現われる特徵的なピークの位置から不働態皮 膜中の $\mathrm{Fe}$ の酸化状態を知ることができる。

このことを確めるために，0.1 N-NaOH (pH 12.9) 溶 液中に持ける純 $\mathrm{Fe}$ の変調反射スペクトルを測定した。 その結果を図 3 に示す。 $-1.00 \mathrm{~V}$ から $-0.80 \mathrm{~V}$ までの 低い電位域に护省るスペクトルには紫外域強度の高い ピークが現われる。ピークの位置は $-1.00 \mathrm{~V}$ と拈ける $4.7 \mathrm{eV}$ から: $-0.80 \mathrm{~V}$ に批る $3.6 \mathrm{eV}$ まで電位の上昇 とともに低ェネルギ側に移行する。この電位域では $\mathrm{Fe}$ $(\mathrm{OH})_{2}$ あるいは $\mathrm{Fe}_{3} \mathrm{O}_{4}$ が熱力学的に安定であるので, $3.6 \mathrm{eV}$ より高いエネルギ值のピークは $\mathrm{Fe}(\mathrm{OH})_{2}$ あるい は $\mathrm{Fe}_{3} \mathrm{O}_{4}$ の存在を示していると考兄られる。しかし， ピークの位置が電位に依存して変化することから，この 電位域で形成される皮膜中には $\mathrm{Fe}^{2+}$ イオンと $\mathrm{Fe}^{3+}$ イ オンがともに存在し，それらの割合が電位に依存して変 化すると考光られる。 $-0.60 \mathrm{~V}$ より貴な電位域に和け るスペクトルには 3.2 2.8 eVにピークが現われる。こ の電位域では $\mathrm{Fe}_{2} \mathrm{O}_{3}$ が熱力学的に安定であるので, $3 \mathrm{eV}$ 付近のピークは $\mathrm{Fe}^{3+}$ イオンの存在に由来すると考えら れる。中性のほう酸緩衝液中に抢ける純 $\mathrm{Fe}$ の変調反射 スペクトルにも $3 \mathrm{eV}$ 付近にピークが現われ， $\mathrm{Fe}_{2} \mathrm{O}_{3}$ に 由来するピークと考兄られている ${ }^{13)}$ 。

図 2 (b) 飞执いて, $1 \mathrm{M}-\mathrm{Na}_{2} \mathrm{SO}_{4}(\mathrm{pH} 2.0)$ 溶液中の $+1.10 \mathrm{~V}$ 以下の電位に拈ける变調反射スペクトルはいず れも $3 \mathrm{eV}$ 付近に最大ピークを有しているので,この電位 域で形成される不働態皮膜は主として 3 価の $\mathrm{Fe}$ 酸化物 $\left(\mathrm{Fe}_{2} \mathrm{O}_{3}\right)$ から成っていると考えられる。また $4 \mathrm{eV}$ 付近 の肩ないしピークは $\mathrm{Fe}^{2+}$ イオンの存在を示するのかも しれない。なぜなら，前述のようにアルカリ性溶液中で 


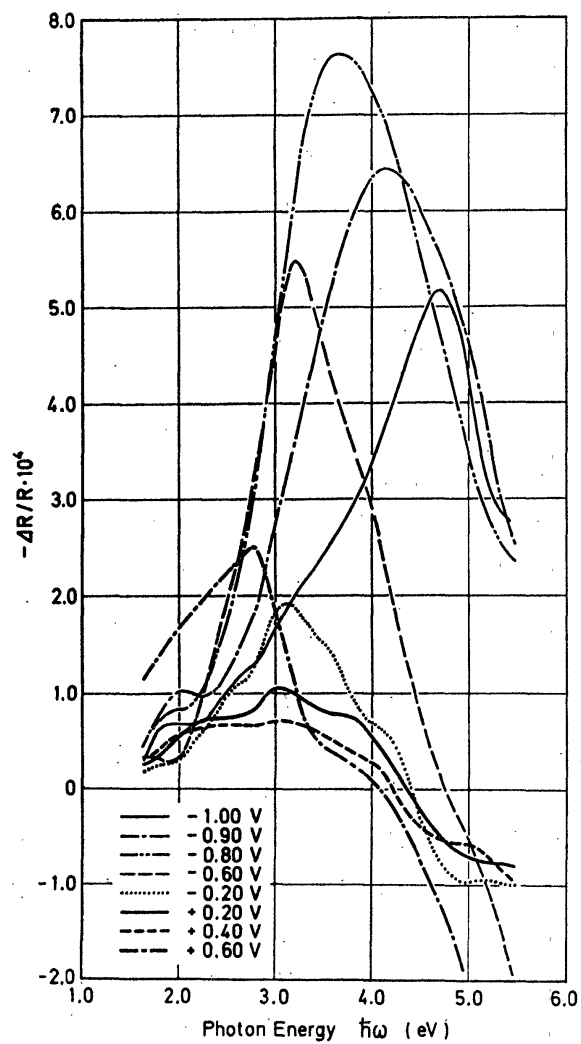

Fig. 3. Modulated reflection spectra for iron at various potentials in $0.1 \mathrm{~N}-\mathrm{NaOH}(\mathrm{pH}$ 12.9).

$\mathrm{Fe}(\mathrm{OH})_{2}$ あるいは $\mathrm{Fe}_{3} \mathrm{O}_{4}$ が安定に存在する電位に和け るスペクトルに 3.6 4.7 eV にピークが現われるからで ある。したがって, 酸性溶液中での皮膜にも $\mathrm{Fe}^{2+} \cdot$ イオ ンが存在すると推察され, さらに $3 \mathrm{eV}$ 付近のピークの 位置が電位によって多少シフトしていることから, 皮膜 中の $\mathrm{Fe}^{2+}$ イオンと $\mathrm{Fe}^{3+}$ イオンの割合に電位依存性が あると考えることがでさる。ただし，この $3 \mathrm{eV}$ 付近の ピーク位置のシフトについては, 皮膜表面に掓るエネ ルギバンドの泆曲を考慮することによっても説明するこ とができる。なわち, 皮膜の表面に電位に依存してバ ンドが湾曲する層*が存在するとすれば, Franz-Keldysh 効果**によってその表面層の光吸収曲線はバンドの湾曲

* いわゆる空間電荷層に相当する。 $\mathrm{Fe}$ の不働態皮 膜の表面にこのような層が存在することが Schultz らによって指摘されている ${ }^{21)} 。$

** 半導体の光物性の分野で光吸収の電界効果として 良く知られている。高電場の下に拈かれた半導体 では, トンネル効果によって価電子帯の頂上を越 えて禁制帯中にも電子が浸み出すため, 本来のバ ソドギャップより小さなエネルギの光を吸収して 電子遷移が起こり, 吸収のブロードニングが起こ $ろ^{22)}$ 。
が大きい程低エネルギ側に尾を引くことになり，その結 果吸収端の見掛け上のシフトが生ずる。このことは不働 態皮膜のもつ半導体的性質と密接に関係していると考之 られるので，今後詳しく検討する必要があろう。

\section{2 純 $\mathrm{Cr}$ の変調反射スペクトル}

$1 \mathrm{M}-\mathrm{Na}_{2} \mathrm{SO}_{4}(\mathrm{pH} 2.0)$ 溶液中に淤子る純 $\mathrm{Cr}$ のアノー ド分極曲線と変調反射スペクトルの電位による变化を図 4 (a) および (b) に示す。不働態および過不㗢態域のいず れの電位に和けるスペクトルにも $5 \mathrm{eV}$ 付近に最大ピー クが現われる。このピークの位置は電位の上昇とともに

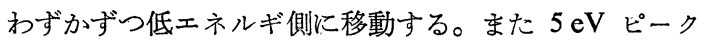
の強度は $+0.40 \mathrm{~V}$ までは電位によって注とんど变化し ないが, $+0.50 \mathrm{~V}$ 以上では電位の上昇とともに大きくな る。 $+0.40 \mathrm{~V}$ 以上の電位に淤るスペクトルには $3.1 \mathrm{eV}$ 付近にもピークが現われ， $+0.80 \mathrm{~V}$ 以上の電位に拉ける スペクトルにはさらに $3.7 \mathrm{eV}$ 付近にもピークが現われ る。これらのピークの強度も電位の上昇とともに大きく なる。

コランダム中の $\mathrm{Cr}^{3+}$ イオンの吸収スペクトルには,
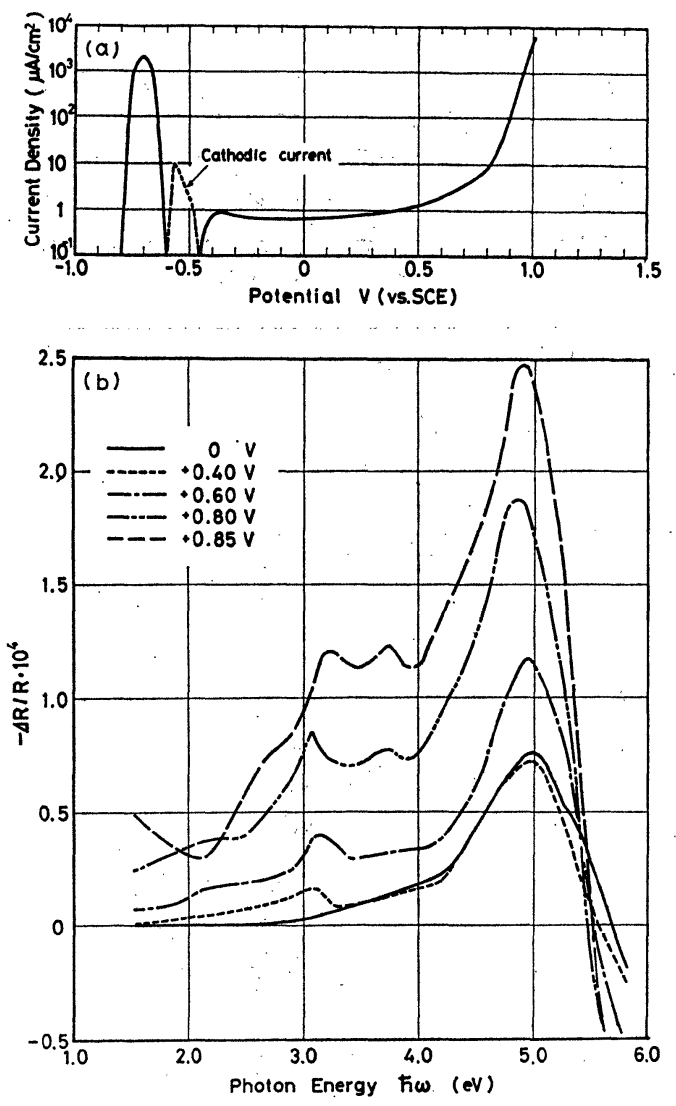

Fig. 4. Anodic polarization curve (a) and modulated reflection spectra (b) for chromium in $1 \mathrm{M}-\mathrm{Na}_{2} \mathrm{SO}_{4}(\mathrm{pH} 2.0$ ). 
2.2, 3.1 および $4.8 \mathrm{eV}$ にピークをもつ配位子場吸収带と $5 \mathrm{eV}$ 付近から始まり $6.9 \mathrm{eV}$ にピークを生ずる強い電荷 移動吸収帯が観察されている ${ }^{23,24)}$ 。一方, $\mathrm{K}_{2} \mathrm{Cr}_{2} \mathrm{O}_{7}$ 水溶 液の吸収スペクトルには $3.6 \mathrm{eV}$ に吸收ピークが現われ る ${ }^{25)}$ 。したがって, 純 $\mathrm{Cr}$ の変調反射スペクトルに現わ れる 3.1 および $5.0 \mathrm{eV}$ のピークは不働態皮膜中の $\mathrm{Cr}^{3+}$ イオンに起因し， $3.7 \mathrm{eV}$ のピークは皮膜中の $\mathrm{Cr}^{6+}$ イオ ンに起因すると考兄られる。したがって，0〜 +0.6Vに 执いて純 $\mathrm{Cr}$ 上飞生成する不働態皮膜は 3 価の $\mathrm{Cr}$ 酸化 物で構成されているが，この皮膜中には $\mathrm{Cr}-\mathrm{OH}$ 結合と $\mathrm{Cr}-\mathrm{O}$ 結合が存在することが知られているので26), 一般 飞 $\mathrm{Cr}_{2} \mathrm{O}_{3} \cdot n \mathrm{H}_{2} \mathrm{O}$ として表わすことができると考学られ る。 $+0.8 \mathrm{~V}$ 以上の電位で生成する過不働態皮膜も主と して 3 価の $\mathrm{Cr}$ 酸化物から成っているが，この皮膜中に は少量の $\mathrm{Cr}^{8+}$ イオンが含まれていると考兄られる。

\section{3 純 Ni の変調反射スペクトル}

$1 \mathrm{M}-\mathrm{Na}_{2} \mathrm{SO}_{4}(\mathrm{pH} 2.0)$ 溶液中に抢ける純 $\mathrm{Ni}$ のアノー ド分極曲線と变調反射スペクトルの電位による変化を図 5 (a) および (b) に示す。アノード分極曲線からこの溶液 中に执いて純 $\mathrm{Ni}$ は $+1.40 \mathrm{~V}$ 以上の電位で二次不㗢態
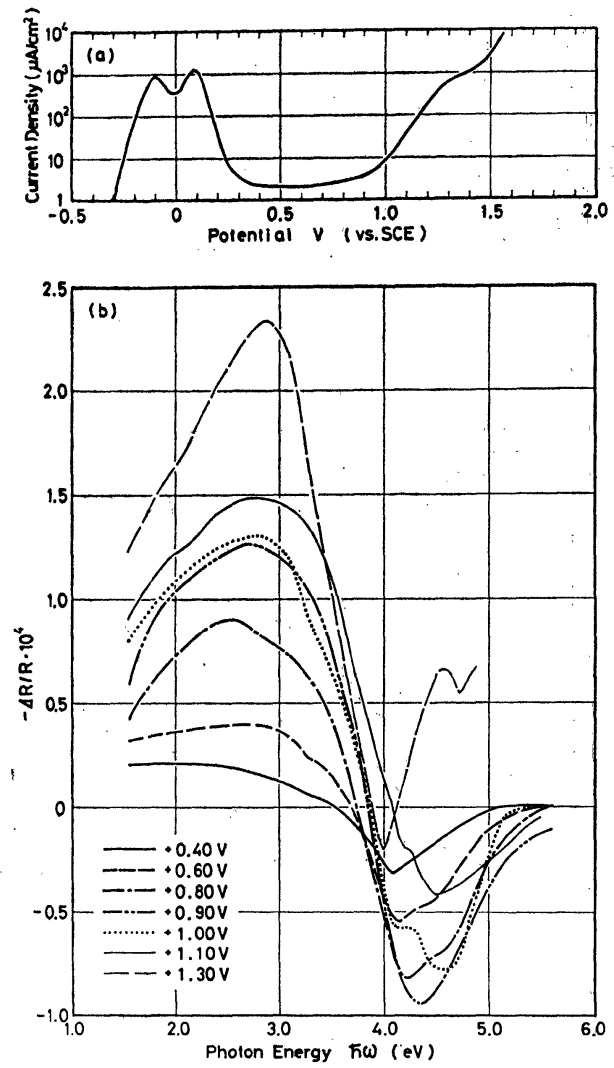

Fig. 5. Anodic polarization curve (a) and modulated reflection spectra (b) for nickel in $1 \mathrm{M}-\mathrm{Na}_{2} \mathrm{SO}_{4}(\mathrm{pH} 2.0)$.
化することが推察されるが，過不働態溶解によって表面 が著しくエッチングされるため， $+1.40 \mathrm{~V}$ 以上の電位に おけるスペクトルは測定できなかった。図 5 (b)による と，測定したすべての電位におけるスペクトルは $3.8 \mathrm{eV}$ 付近で $-\Delta R / R$ の符号が反転し, $2.6 \sim 2.9 \mathrm{eV}$ に正の ピーク，4.0 4.6 eV に負のピークを示す。ただし， $+0.40 \mathrm{~V}$ および $+0.60 \mathrm{~V}$ に抢けるスペクトルには明瞭 な正のピークは認められない。正負いずれのピークも電 位によってその位置と強度が变化する。正のピークの位 置は電位の上昇とともに $+0.80 \mathrm{~V}$ に掓る $2.6 \mathrm{eV}$ から $+1.30 \mathrm{~V}$ 飞打ける $2.9 \mathrm{eV}$ まで移動し, 同時にピーク強 度は大きくなる。一方, 負のピークの位置は $+0.40 \mathrm{~V}$ 扰よび $+0.60 \mathrm{~V}$ に抢ける $4.1 \mathrm{eV}$ から電位の上昇とと もに高エネルギ側に移動し $+1.00 \mathrm{~V}$ で $4.6 \mathrm{eV}$ に達し たのち, $+1.10 \mathrm{~V}$ 以上では再び低ェネルギ側と移動す る。負のピークの強度は + $0.90 \mathrm{~V}$ で最大值を示し, $+1.00 \mathrm{~V}$ 以上では電位の上昇とともに低くなる。この ような負のピークの位置と強度の電位による変化は Paatsch $5^{7,8)}$ が $0.1 \mathrm{~N}-\mathrm{H}_{2} \mathrm{SO}_{4}$ 溶液中に招いて入射角 $45^{\circ}$ で得た結果とほぼ類似しているが， $+1.10 \mathrm{~V}$ 以上の 電位に㧊けるピーク位置の低エネルギ側への移動は彼ら の得たスペクトルには見られない。また，2.6 2.9 eV に現われる比較的強度の高いピークも彼らの得たスペク トルには認められない。これらの相違が生じた原因の 1 つとして，入射角によって測定感度が異なることが挙げ られる。

2 価の $\mathrm{Ni}$ 酸化物である $\mathrm{NiO}$ は $3.7 \sim 4.0 \mathrm{eV}$ に吸収 端を有しており ${ }^{27,28)}$ ，このエネルギ值付近において NiO の複素屈折率の実部 $n$ は $2 \sim 3$ の間で, 虚部 $k$ は $0 \sim 1.2$ の間で著しく変化する ${ }^{28)}$ 。一方， $\mathrm{Ni}^{3+}$ イオンを含むコ ランダムの吸収スペクトルには，3.2, 4.6 抢よび $7.0 \mathrm{eV}$ にピークを生ずる電荷移動吸収帯が観察されている ${ }^{23)}$ 。 図 5 (b) に招いて，不働態域の電位である $+0.40 \mathrm{~V}$ お よび $+0.60 \mathrm{~V}$ に淤けるスペクトルには $4.1 \mathrm{eV}$ に負の ピークが現れるので, この電位域で形成される $\mathrm{Ni}$ の不 働態皮膜は 2 価の $\mathrm{Ni}$ 酸化物であると考兄られる。一 方, $+0.80 \mathrm{~V}$ から過不働態域の $+1.10 \mathrm{~V}$ までの電位域 に拉けるスペクトルには. 2.6 2.8 eV に正のピークが現 われ，負のピークは電位の上昇とともに高ェネルギ側化 移動し $+1.00 \mathrm{~V}$ で $4.6 \mathrm{eV}$ になる。したがって，この 電位域では皮膜中に $\mathrm{Ni}^{3+}$ イオンが存在し, その量は電 位が貴なほど多くなると推察される。過不動態溶解速度 の大きい電位である $+1.30 \mathrm{~V}$ に打けるスペクトルは 2.9 打よび $4.0 \mathrm{eV}$ 飞鋭い正負のピークを有しており， $4.6 \mathrm{eV}$ 付近にも小さなピークを示す。このような特徴を 有するスペクトルは皮膜中の $\mathrm{Ni}_{2} \mathrm{O}_{3}$ 沉起因することが， 変調反射スペクトルの pHによる变化を調ベた実験結果 


\section{から推察されている ${ }^{29)}$ 。}

\section{$3.4 \mathrm{Fe}-\mathrm{Cr}$ 合金の変調反射スペクトル}

$1 \mathrm{M}-\mathrm{Na}_{2} \mathrm{SO}_{4}(\mathrm{pH} 2.0)$ 溶液中に抒将る $\mathrm{Fe}-20 \mathrm{Cr}$ 合金 のアノード分極曲線と变調反射スペクトルの電位による 変化を図 $6(\mathrm{a})$ および (b) に示す。この溶液中における $\mathrm{Fe}-20 \mathrm{Cr}$ 合金のアノード分極曲線上には不㗢態, 過不 働態および二次不働態の各領域が明瞭に現われ，それら の各領域において得られた変調反射スペクトルは互いに 異なった特徵を有している。変調反射スペクトルの形お よび特徵的なピークの位置から, 各領域で形成される皮 膜の化学組成は以下のように推察される。

（1）不働態皮膜：不働態域内の $+0.40 \mathrm{~V}$ 以下の電 位に拈けるスペクトルには $4.8 \mathrm{eV}$ に最大ピークが現わ れ， $4 \mathrm{eV}$ 付近に肩ないし小さなピークが現われる。こ れらのスペクトルの形は同じ電位域に和ける純 $\mathrm{Cr}$ のス ペクトル (図 4 (b)) と似ており, 最大ピークの位置もほ ぼ一致している。したがって，この電位域で形成される 不働態皮膜は主として $\mathrm{Cr}_{2} \mathrm{O}_{3} \cdot n \mathrm{H}_{2} \mathrm{O}$ から成っていると 考えられる。しかし， $4 \mathrm{eV}$ 付近の肩ないし小さなピー クは純 Cr のスペクトルには認められず，しかも比較的 高エネルギ側にあることから，これらの肩ないしピーク
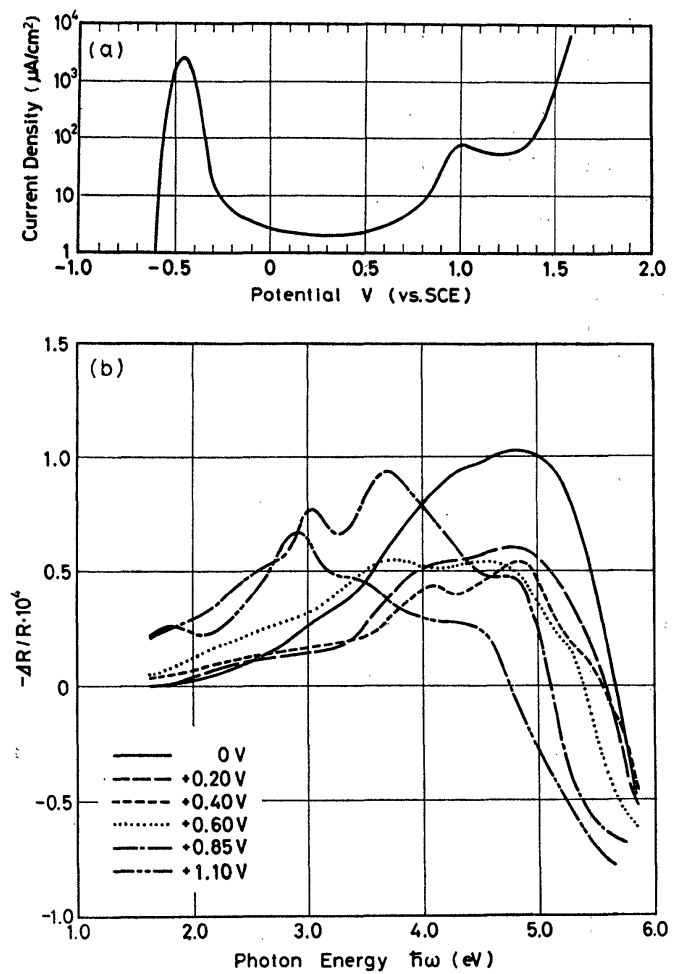

Fig. 6. Anodic polarization curve (a) and modulated reflection spectra (b) for the $\mathrm{Fe}$ $20 \mathrm{Cr}$ alloy in $1 \mathrm{M}-\mathrm{Na}_{2} \mathrm{SO}_{4}(\mathrm{pH} 2.0)$.
は皮膜中の $\mathrm{Fe}^{2+}$ イオンに由来すると考えられる。ESCA による分析結果も高 $\mathrm{Cr}$ 合金の不働態皮膜中には $\mathrm{Fe}^{2+}$ イオンがかなり存在することを示している3)。同じ不働 態域の電位であっても $+0.40 \mathrm{~V}$ より高い電位では, $+0.60 \mathrm{~V}$ に护けるスペクトルに見られるよらに $4 \mathrm{eV}$ 付 近のピークが低ェネルギ側に移動し，そのピーク強度は 高くなる。したがって, 不働態域内の高い電位で形成さ れる皮膜中には $\mathrm{Fe}^{2+}$ イオンに加えて $\mathrm{Fe}^{3+}$ イオンも多 く存在すると考光られる。

（2）過不働態皮膜: 過不働態域の電位である +0.85 Vに拈けるスペクトルには $3.7 \mathrm{eV}$ に最大のピークが現 われ，そのほか 3.0 拉よび $4.8 \mathrm{eV}$ に 2 つ小さいピー クが現われる。 $3.7 \mathrm{eV}$ のピークは皮膜中の $\mathrm{Fe}^{2+}, \mathrm{Fe}^{3+}$ 拉よび $\mathrm{Cr}^{6+}$ イオンに由来するピークの一部が重なり合 って生じているように思われる。一方, $3.0 \mathrm{eV}$ と $4.8 \mathrm{eV}$ のピークはそれぞれ $\mathrm{Fe}^{3+}$ イオンと $\mathrm{Cr}^{3+}$ イオンの存在 を示している。 $3.0 \mathrm{eV}$ ピークの強度が $4.8 \mathrm{eV}$ ピークの 強度に比べて高いことから，過不働態皮膜中の $\mathrm{Fe}^{3+}$ イ オンの量は $\mathrm{Cr}^{3+}$ イオンの量より多いと考えられる。

（3）二次不働態皮膜; 二次不働態域の電位である $+1.10 \mathrm{~V}$ に护けるスペクトルには $2.8 \mathrm{eV}$ に最大ピーク が現われ， $4.5 \mathrm{eV} に$ 肩が現われる。このスペクトルの 形は同じ電位に和ける純 Feのスペクトル (図 2 (b)) の 形と良く似ている。したがって，二次不働態皮膜の組成 は $\mathrm{Fe}$ の不働態皮膜の組成と類似していると考えられ る。すなわち，二次不働態皮膜は主として $\mathrm{Fe}_{2} \mathrm{O}_{3}$ から 成っていると考えられる。また， $4.5 \mathrm{eV} に$ 肩が現われる ことは皮膜中に $\mathrm{Cr}^{3+}$ および $\mathrm{Cr}^{6+}$ イオンが少量存在す ることを示しているよらに思われる。

得られた変調反射スペクトルから皮膜の化学組成を定 量的に分析するためには，スペクトルに現われる特徵的 なピークの強度を求めなければならない。しかし，ピー ク強度を化学種の存在量と関係づけて正確に決定するこ とは難しい。なぜなら，ピーク強度に及ぼす膜厚や下地 合金の光学定数などの諸因子の影響を正確に評価するこ とは現段階ではほとんど不可能であるし，しばしばピー ク分離すら困難である。そこで，ここでは皮膜組成の変 化を概略的に表わすために，変調反射スペクトルに現わ れる最大ピークのエネルギ值 $\left(\hbar \omega_{m . p .}\right.$.) を用いた。

図 7 は, $\mathrm{Fe}-20 \mathrm{Cr}$ 合金の変調区射スペクトルから求 めた $h \omega_{m . p}$. . の電位による变化を示す。図中には，比較 のため, 純 $\mathrm{Fe}$ および純 $\mathrm{Cr}$ の変調反射スペクトルから 求めた $\hbar \omega_{m . p}$. 女示した。 $\mathrm{Fe}-20 \mathrm{Cr}$ 合金の $\hbar \omega_{m . p}$. の 值は $+0.40 \mathrm{~V}$ 以下ではほとんど電位に依存しておらず 純 $\mathrm{Cr}$ の $\hbar \omega_{m . p}$. 值に近いが, $+0.60 \mathrm{~V}$ 以上では電位 が高くなるにつれて急激に減少し，2次不働態域内の $+1.10 \mathrm{~V}$ で純 $\mathrm{Fe}$ の $\hbar \omega_{m . p}$. 值に近くなる。このような 


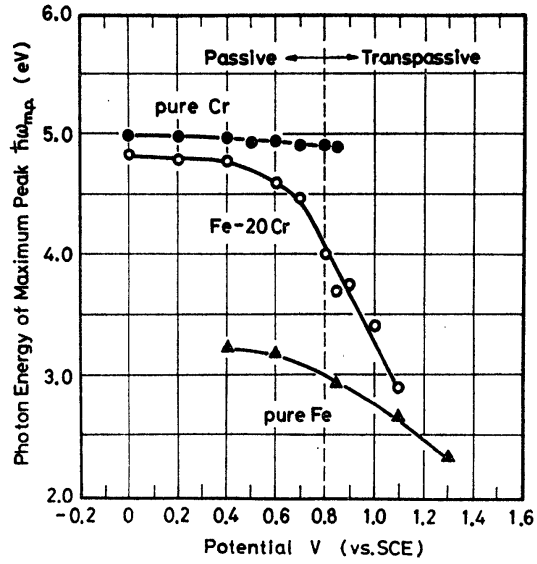

Fig. 7. Changes in the photon energies of the maximum peaks, $\hbar \omega_{m . p .}$, in the modulated reflection spectra for iron, chromium, and the $\mathrm{Fe}-20 \mathrm{Cr}$ alloy as a function of potential in $1 \mathrm{M}-\mathrm{Na}_{2} \mathrm{SO}_{4}(\mathrm{pH} 2.0)$.

$\hbar \omega_{m . p}$. の変化か ら, $\mathrm{Fe}-20 \mathrm{Cr}$ 合金の不働態皮膜中に $\mathrm{Cr}^{3+}$ イオンが濃縮していること拉よび過不働態溶解開 始電位 (約 $0.8 \mathrm{~V}$ ) より約 $0.2 \mathrm{~V}$ 卑な電位である $+0.60 \mathrm{~V}$ から皮膜組成に変化が生ずることがわかる。過不働態溶 解開始電位より卑な電位において皮膜組成に変化が生ず る可能性は電極インピーダンス測定の結果から女推察さ れている ${ }^{30,31) 。 ~}$

次に，不働態皮膜の化学組成に及ぼす合金の $\mathrm{Cr}$ 含有 量の影響を調べるために, Cr 含有量の異なる一連の $\mathrm{Fe}$ $\mathrm{Cr}$ 合金 $(5 \sim 70 \% \mathrm{Cr})$ について, $1 \mathrm{M}-\mathrm{Na}_{2} \mathrm{SO}_{4}(\mathrm{pH} 2.0)$ 溶液中における変調反射スペクトルを測定した。

図 8 は，+0.40 V で不働態化した一連の Fe-Cr 合金, 純 $\mathrm{Fe}$ および純 $\mathrm{Cr}$ の変調反射スペクトルを示す。 $\mathrm{Fe}$ -

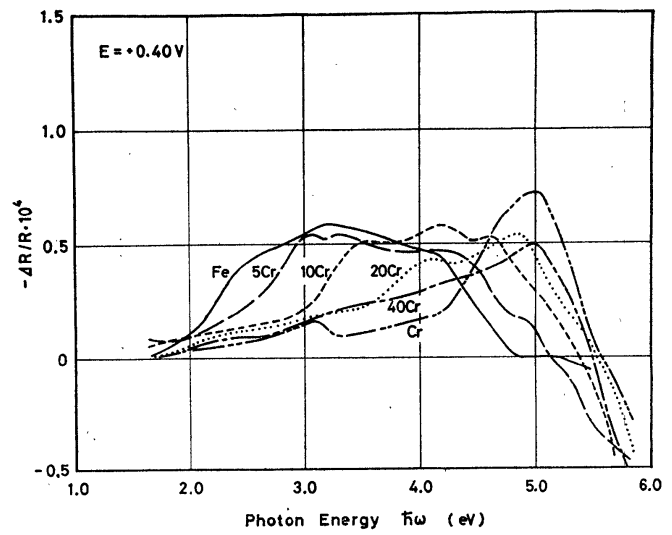

Fig. 8. Modulated reflection spectra for iron, chromium, and $\mathrm{Fe}-\mathrm{Cr}$ alloys (5 to $40 \%$ $\mathrm{Cr})$ at $+0.40 \mathrm{~V}$ in $1 \mathrm{M}-\mathrm{Na}_{2} \mathrm{SO}_{4}(\mathrm{pH} 2.0$ ).
$\mathrm{Cr}$ 合金のスペクトルの形は合金の $\mathrm{Cr}$ 含有量によって 著しく異なるが， $\mathrm{Cr}$ 含有量が $10 \%$ 以下の合金のスペ クトルは純 $\mathrm{Fe}$ のスペクトルと似ており，20\%以上の $\mathrm{Cr}$ を含む合金のスペクトルは純 $\mathrm{Cr}$ のスペクトルと似 ている。合金の $\mathrm{Cr}$ 含有量によってスペクトルの強度は ほとんど変化しないが，スペクトルに現われる最大ピー クの位置は著しく変化する。図 9 は， $+0.40 \mathrm{~V}$ で測定し

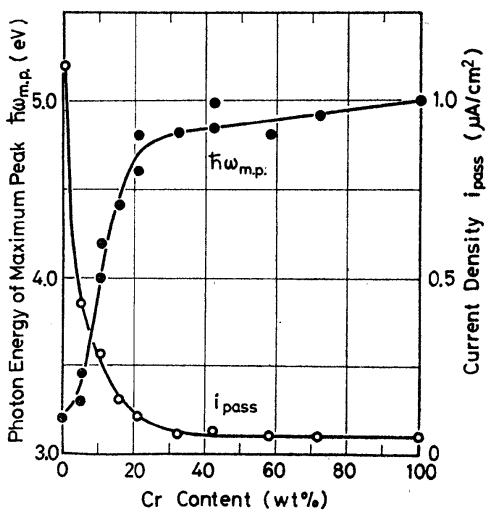

Fig. 9. Changes in the photon energy of the maximum peak, $\hbar \omega_{m . p .}$, in the modulated reflection spectrum and the current density in the passive state, $i_{\text {pass }}$, for $\mathrm{Fe}-\mathrm{Cr}$ alloys at $+0.40 \mathrm{~V}$ in $1 \mathrm{M}-\mathrm{Na}_{2} \mathrm{SO}_{4}(\mathrm{pH} 2.0)$ as a function of $\mathrm{Cr}$ content.

た $\mathrm{Fe}-\mathrm{Cr}$ 合金の変調反射スペクトルから求めた最大ピ 一クのエネルギ値 $\left(\hbar \omega_{m . p .}\right)$ の合金の $\mathrm{Cr}$ 含有量による

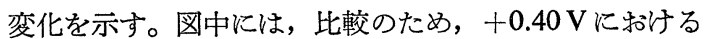
不働態維持電流密度 $\left(i_{\text {pass }}\right)$ も示した。 $\mathrm{Cr}$ 含有量が 0 $20 \%$ の範囲に和いては, $\mathrm{Cr}$ 含有量の增加とともに $\hbar \omega_{m . p .}$ が著しく高くなり，同時に $i_{\text {pass }}$ は急激に減少す る。一方, Cr 含有量が $20 \sim 100 \%$ の範囲では, $\hbar \omega_{m . p}$. と $i_{\text {pass }}$ の $\mathrm{Cr}$ 含有量による変化は小さい。この範囲に 拈ける $\mathrm{Fe}-\mathrm{Cr}$ 合金の $\hbar \omega_{m}$.p. は純 $\mathrm{Cr} の \hbar \omega_{m} . p$. とほ 注等しいことから，20\% 以上の $\mathrm{Cr}$ を含む合金の不㗢態 皮膜は主として $\mathrm{Cr}_{2} \mathrm{O}_{3} \cdot n \mathrm{H}_{2} \mathrm{O}$ から成っていることがわ かる。Cr 含有量が $0 \sim 20 \%$ の範囲に和ける $\hbar \omega_{m}$.p. の 増加とそれに対応する $i_{\text {pass }}$ の急激な減少は，皮膜中の 3 価の $\mathrm{Cr}$ 酸化物の量が増光, 主として $\mathrm{Cr}_{2} \mathrm{O}_{3} \cdot n \mathrm{H}_{2} \mathrm{O}$ から成る皮膜が形成されるにつれて合金の耐食性が改善 されることを示している。

図 10 は，+0.85 V に护ける一連の $\mathrm{Fe}-\mathrm{Cr}$ 合金，純 $\mathrm{Fe}$ 扎よび純 $\mathrm{Cr}$ の変調反射スペクトルを示す。 $+0.85 \mathrm{~V}$ に拈いて，10\%以上の $\mathrm{Cr}$ を含む合金はアノード分極 曲線上に過不働態溶解による電流の増加を示す。図10に よると，合金の $\mathrm{Cr}$ 含有量が増すにつれてスペクトルに 現われる最大ピークの強度と $h \omega_{m, p .}$. がともに大きくな 


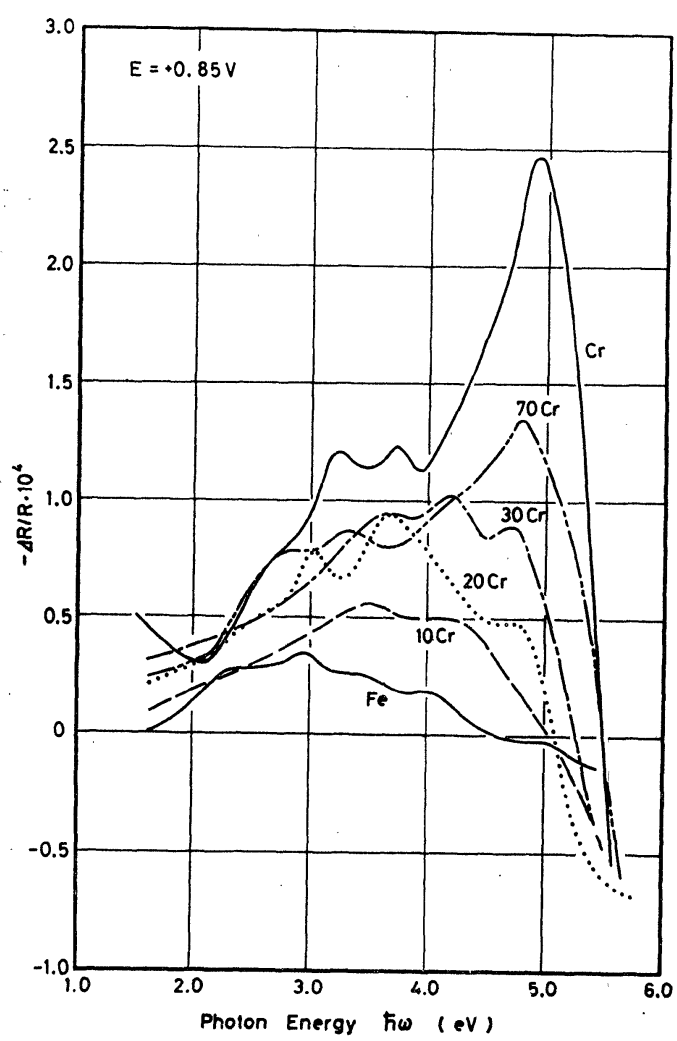

Fig. 10. Modulated reflection spectra for iron, chromium, and $\mathrm{Fe}-\mathrm{Cr}$ alloys (10 to $70 \%$ $\mathrm{Cr})$ at $+0.85 \mathrm{~V}$ in $1 \mathrm{M}-\mathrm{Na}_{2} \mathrm{SO}_{4}(\mathrm{pH} 2.0)$.

ることがわかる。Cr 含有量の增加による $\hbar \omega_{m . p}$. の変 化は 0 40\%のの範囲で特に大きい。 $40 \%$ 以上の $\mathrm{Cr}$ を 含む合金の $\hbar \omega_{m . p}$. . 値は純 $\mathrm{Cr}$ の $\hbar \omega_{m . p}$. の値 $(4.9 \mathrm{eV})$ に注涪近いことから，これらの合金上には主として $\mathrm{Cr}_{2}$ $\mathrm{O}_{3} \cdot n \mathrm{H}_{2} \mathrm{O}$ から成る皮膜が形成されると考学られる。一 方, $\mathrm{Cr}$ 含有量が $20 \%$ 以下の合金のスペクトルには $3 \mathrm{eV}$ 付近に大さなピークが現われ, $\mathrm{Cr}^{3+}$ イオンの存在 を示す $4.8 \mathrm{eV}$ のピークは小さくなるかあるいは忹とん ど認められなくなる。したがって，これらの合金上に生 成する皮膜は主として $\mathrm{Fe}_{2} \mathrm{O}_{3}$ から成っていることが推 察される。

図 11 は，+1.10 V で測定した $\mathrm{Fe}-\mathrm{Cr}$ 合金の変調反 射スペクトルの $\mathrm{Cr}$ 含有量による变化を示す。この電位 に执いて $30 \%$ 以下の $\mathrm{Cr}$ を含む合金は二次不働態化す るが, $\mathrm{Fe}-30 \mathrm{Cr}$ 合金では $1 \mathrm{~mA} / \mathrm{cm}^{2}$ 位の高いアノード 溶解電流密度を示し表面がひどくエッチングされるた め，スペクトルの測定はできなかった。 $20 \%$ 以下の $\mathrm{Cr}$ を含む合金では +1.10 V 飞お和電流密度は $20 \mu \mathrm{A} /$ $\mathrm{cm}^{2}$ 以下であり, 表面はほとんどェッチングされなかっ た。図11によると，いずれの合金のスペクトルも純 $\mathrm{Fe}$ のスペクトルと似て折り, $2.9 \mathrm{eV}$ 付近に極大ピークを示

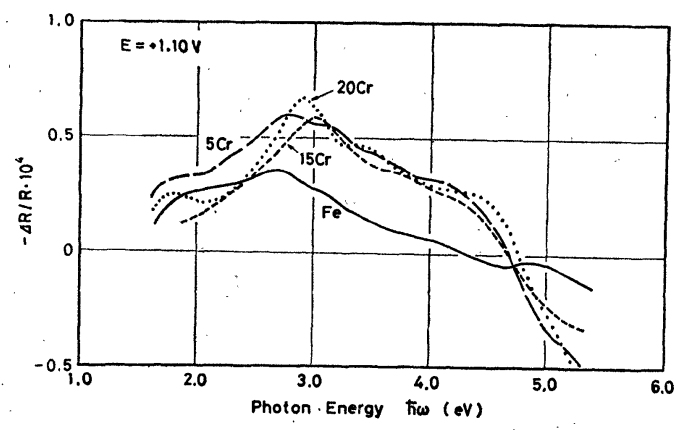

Fig. 11. Modulated reflection spectra for iron and $\mathrm{Fe}-\mathrm{Cr}$ alloys $(5$ to $20 \% \mathrm{Cr}$ ) at +1.10 $\mathrm{V}$ in $1 \mathrm{M}-\mathrm{Na}_{2} \mathrm{SO}_{4}$ (pH 2.0).

す。しかし， $4.5 \mathrm{eV}$ 付近には皮膜中の $\mathrm{Cr}^{3+}$ 拉よび $\mathrm{Cr}^{6+}$ イオンによると思われる肩が現われる。したがって，こ れらの合金の二次不㗢態皮膜の主成分は $\mathrm{Fe}_{2} \mathrm{O}_{3}$ である が，この皮膜には少量の $\mathrm{Cr}^{3+}$ 抢よび $\mathrm{Cr}^{6+}$ イオンも含 まれていると考㝋られる。

\section{$3.520 \mathrm{Cr}-25 \mathrm{Ni}$ 鋼の变調反射スペクトル}

空気中にとり出された $20 \mathrm{Cr}-25 \mathrm{Ni}$ 鋼の不働態皮膜中 では Ni は2 価のイオンの状態で存在することが報告さ れている ${ }^{32}$ 。しかし, 水溶液中で生成したままの皮膜中
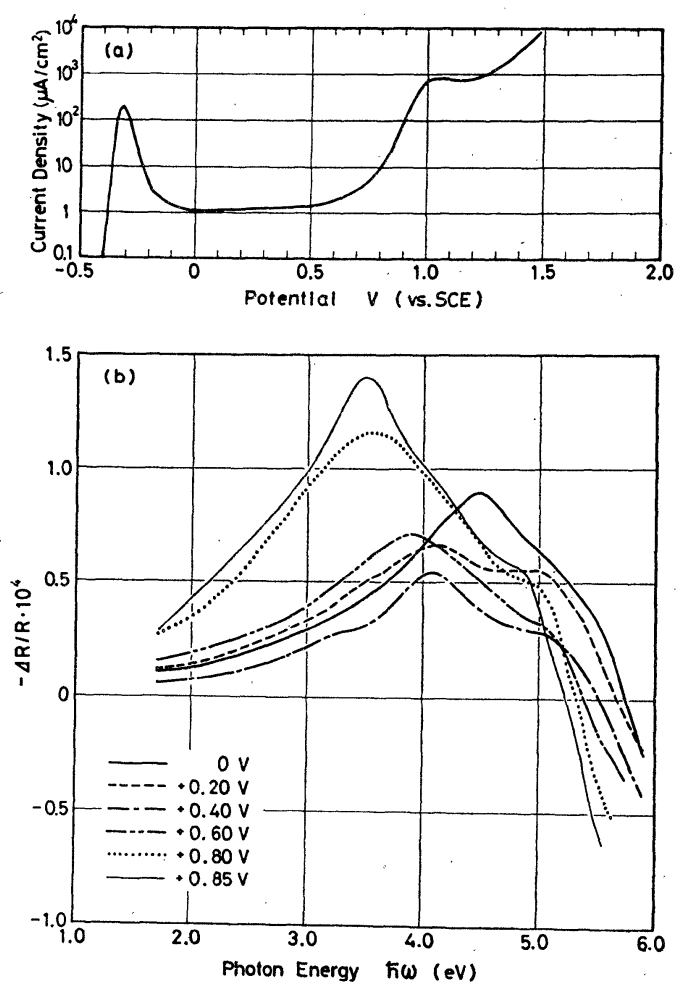

Fig. 12. Anodic polarization curve (a) and modulated reflection spectra (b) for the $20 \mathrm{Cr}-$ $25 \mathrm{Ni}$ steel in $1 \mathrm{M}-\mathrm{Na}_{2} \mathrm{SO}_{4}(\mathrm{pH} 2.0$ ). 
に怙ける Ni の存在状態についてはまだわかっていな い。そこで, $20 \mathrm{Cr}-25 \mathrm{Ni}$ 鋼の $1 \mathrm{M}-\mathrm{Na}_{2} \mathrm{SO}_{4}(\mathrm{pH} 2.0)$ 溶 液中における変調反射スペクトルを測定し，これに基づ いて皮膜中の $\mathrm{Ni}$ の存在状態を検討した。

図 12 (a) 抢よび (b) に，20 Cr-25 Ni 鋼のアノード分 極曲線と変調反射スペクトルの電位による変化を示す。 アノード分極曲線上には $+1.0 \mathrm{~V}$ 以上の電位域に二次不 働態域が観察されるが，ここでは電流密度が大きく $\left(\approx 1 \mathrm{~mA} / \mathrm{cm}^{2}\right)$ 表面がひどくェッチングされるため, 変 調反射スペクトルは測定できなかった。四 12 (b)による と, 不働態域の $0 \sim+0.60 \mathrm{~V}$ の電位域に叔けるスペクト ルには $4.5 \sim 3.9 \mathrm{eV}$ に最大ピークが現われ, $5 \mathrm{eV}$ 付近 に肩が認められる。最大ピークの位置 $\left(\hbar \omega_{m . p .}\right)$ は電位 の上昇とともに低エネルギ側に移動する。 $\mathrm{Fe}-20 \mathrm{Cr}$ 合 金のスペクトル (図 6(b)) と比較すると, $20 \mathrm{Cr}-25 \mathrm{Ni}$ 鋼の $\hbar \omega_{m . p .}$. の值は同じ電位に括ける $\mathrm{Fe}-20 \mathrm{Cr}$ 合金の $\hbar \omega_{m . p .}$. の值より $0.4 \sim 0.7 \mathrm{eV}$ だけ低くなっている。過 不働態域の電位である $+0.80 \mathrm{~V}$ 打よび $+0.85 \mathrm{~V}$ に拉 けるスペクトルは，それぞれ $3.6 \mathrm{eV}$ および $3.4 \mathrm{eV}$ に 最大ピークを示し， $4.9 \mathrm{eV}$ 付近に肩を生ずる。これらの スペクトルの形は過不働態域に淤ける $\mathrm{Fe}-20 \mathrm{Cr}$ 合金の スペクトルと類似している。

不働態域の電位に括ける変調反射スペクトルが $20 \mathrm{Cr}$ $25 \mathrm{Ni}$ 鋼と $\mathrm{Fe}-20 \mathrm{Cr}$ 合金とで相違していることは, $20 \mathrm{Cr}-25 \mathrm{Ni}$ 鋼の不働態皮膜中に Ni 酸化物が存在する ことによると考㝋られる。しかし，20 Cr-25 Ni 鋼のス ペクトルには純 Ni のスペクトル (図 $5(\mathrm{~b}))$ に見られた ような $4.1 \mathrm{eV}$ の負のピークは認められないことから， 皮膜中の $\mathrm{Ni}$ 酸化物の存在量は少ないと考穴られる。前 述したように 2 価の $\mathrm{Ni}$ 酸化物である $\mathrm{NiO}$ は約 $4 \mathrm{eV}$ に 吸収端を有しておう， $4 \mathrm{eV}$ 以上のエネルギの光を強く 吸収する (吸収係数 $\alpha \approx 5 \times 10^{5} \mathrm{~cm}^{-1}$ ) $^{27)}$ 。したがって, $5 \mathrm{eV}$ 付近までは弱い四収しか示さない $\mathrm{Cr}_{2} \mathrm{O}_{3} \cdot n \mathrm{H}_{2} \mathrm{O}$ か ら成る皮膜に $\mathrm{Ni}^{2+}$ イオンが少量含まれるだけでも, 皮 膜の吸収曲線は低エネルギ側に尾を引くようになり, 最 大ピークが低エネルギ側に移動する可能性がある。いず れの電位に捯けるスペクトルにも $5 \mathrm{eV}$ 付近に肩が現わ れるが，この肩は明らかに $\mathrm{Cr}^{3+}$ イオンに由来するもの である。

過不働態域に抢ける $20 \mathrm{Cr}-25 \mathrm{Ni}$ 鋼の変調反射スペク トルは $\mathrm{Fe}-20 \mathrm{Cr}$ 合金の変調反射スペクトルと類似して おり, 皮膜中の $\mathrm{Ni}$ 酸化物の存在を特徵づけるピークは 観察されない。したがって，過不働態域で形成される皮 膜中の $\mathrm{Ni}$ 酸化物の量子やはり少ないと考光られる。

以上のことから，鋼中にかなりの量の $\mathrm{Ni}$ が含まれて いても皮膜中に含まれる Ni 酸化物の量はあまり多くな い上らに思われる。1 $18 \mathrm{Cr}-8 \mathrm{Ni}$ 鋼の不働態皮膜を $\mathrm{ESCA}$
を用いて分析した研究 ${ }^{333}$ においても，皮膜中には Ni は ほとんぞ存在していないことが報告されている。

\section{4. 結 論}

酸性の $1 \mathrm{M}-\mathrm{Na}_{2} \mathrm{SO}_{4}$ 溶液 ( $\mathrm{pH}$ 2.0) 中でアノード分極 中の純 $\mathrm{Fe}$, 純 $\mathrm{Cr}$, 純 $\mathrm{Ni}$, 一連の $\mathrm{Fe}-\mathrm{Cr}$ 合金 $(5 \sim 70 \%$ $\mathrm{Cr}$ ) および $20 \mathrm{Cr}-25 \mathrm{Ni}$ 鋼の変調反射スペクトルを測定 した。得られた变調反射スペクトルに現われる特徵的な ピークの位置と強度から表面皮膜の化学組成を推定し た。結果は次のようにをとめられる。

（1）不働態化した純 $\mathrm{Fe}$ の変調反射スペクトルには $3 \mathrm{eV}$ 付近に $\mathrm{Fe}^{3+}$ イオンの存在を示す特徵的な最大ピ 一クが現われるが，そのほか $\mathrm{Fe}^{2+}$ イオンに由来すると 考觉られる肩ないし小さなピークも存在する。したがっ て, 純 $\mathrm{Fe}$ の不働態皮膜は $\mathrm{Fe}^{2+}$ イオンを少量含む 3 価 の $\mathrm{Fe}$ 酸化物から成っていると考学られる。最大ピーク の位置 (光子ェネルギ值) には電位によるシフトが認め られる。このシフトは皮膜中の $\mathrm{Fe}^{2+}$ イオンの存在量の 変化あるいは皮膜表面に㨟けるエネルギバンドの湾曲を 考慮することによって説明できる。

（2）不働態域に护ける純 $\mathrm{Cr}$ の変調反射スペクトル には $5.0 \mathrm{eV}$ に $\mathrm{Cr}^{3+}$ イオンに由来する最大ピークが現 われる。過不働態域に拈けるスペクトルには $5 \mathrm{eV}$ 付近 の最大ピークのほかに $3.7 \mathrm{eV} に \mathrm{Cr}^{8+}$ イオンに由来す る小さいピークが現われる。したがって, 純 $\mathrm{Cr}$ の不働 態怙よび過不働態皮膜はいずれも主成分は 3 価の $\mathrm{Cr}$ 酸 化物であるが，過不働態皮膜中には少量の $\mathrm{Cr}^{6+}$ イオン が含まれていると考えられる。

(3) 不働態域の電位に淤ける純 $\mathrm{Ni}$ の変調反射スペ クトルには $\mathrm{Ni}^{2+}$ イオンの存在を示す負のピークが 41 $\mathrm{eV}$ に現われる。したがって, 純 $\mathrm{Ni}$ の不働態皮膜は 2 価の Ni 酸化物であると考えられる。過不働態域におけ るスペクトルには $\mathrm{Ni}^{3+}$ イオンに由来すると考觉られる 正のピークが $2.6 \sim 2.9 \mathrm{eV}$ に現われ, 負のピークの位置 る変化することから, 過不働態域では電位の上昇ととも に皮膜中の $\mathrm{Ni}^{3+}$ イオンの量が増加することが推察され る。

（4）不働態域の電位である $+0.40 \mathrm{~V}$ と括ける Fe$\mathrm{Cr}$ 合金の変調反射 スペクトルは合金の $\mathrm{Cr}$ 含有量によ って著しく変化する。スペクトルに現われる最大ピーク の位置の $\mathrm{Cr}$ 含有量による变化から，0 20\% の範囲で は $\mathrm{Cr}$ 含有量の堌加とともに不働態皮膜中の $\mathrm{Cr}^{3+}$ イオ ンの存在量が増加することが推察される。

(5) 不働態域に猢る $\mathrm{Fe}-20 \mathrm{Cr}$ 合金の変調反射ス ペクトルは $4.8 \mathrm{eV}$ に最大ピークを示し, $4 \mathrm{eV}$ に肩ない しピークを生ずる。したがって，この合金の不働態皮膜 は主として 3 価の $\mathrm{Cr}$ 酸化物から成っているが, 皮膜中 
には $\mathrm{Fe}^{2+}$ イオンも存在すると考光られる。過不働態お よび二次不働態域ではスペクトルに現われる最大ピーク の位置が電位に依存して変化することから，皮膜中の $\mathrm{Fe}$ および $\mathrm{Cr}$ イオンの酸化状態と存在割合が変化する ことが推察できる。

（6）不働態域に打ける $20 \mathrm{Cr}-25 \mathrm{Ni}$ 鋼の変調反射ス ペクトルは $\mathrm{Fe}-20 \mathrm{Cr}$ 合金のそれと似ているが，最大ピ 一クの位置は Fe-20 Cr 合金と比較して $0.4 \sim 0.7 \mathrm{eV}$ だ け低エネルギ側にある。したがって，20 Cr-25 Ni 鋼の 不働態皮膜は $\mathrm{Fe}-20 \mathrm{Cr}$ 合金の場合と同様に主として 3 価の $\mathrm{Cr}$ 酸化物で構成されているが，最大ピークの低エ ネルギ側へのシフトから少量の $\mathrm{Ni}$ 酸化物孔存在してい ることが推察される。

(Recieved April 10, 1978)

\section{文献}

1) C. L. McBee \& J. Kruger: Electrochim. Acta, 17, 1337 (1972).

2) J. E. Holliday \& R. P. Frankenthal: J. Electrochem. Soc., 119, 1190 (1972).

3) K. Asami, K. Hashimoto \& S. Shimodaira: Corros. Sci., 16, 387 (1976).

4) A. E. Yaniv, J. B. Lumsden \& R. W. Staehle: J. Electrochem. Soc., 124, 490 (1977).

5) M. da Cunha Belo, B. Rondot, F. Pons, J. Le Hericy \& J. P. Langeron: J. Electrochem. Soc., 124, 1317 (1977).

6）原 信義，杉本克久：防食技術，26, 145 (1977).

7) H. Gobrecht, W. Paatsch \& R. Thull: Ber. Bunsenges. physik. Chem., 75, 1353 (1971).

8) W. Paatsch: Ber. Bunsenges. physik. Chem., 77, 895 (1973).

9) W. Paatsch: Surf. Sci., 37, 59.(1973).

10) W. Paatsch: Ber Bunsenges. physik. Chem., 79, 922 (1975).

11) W. Paatsch: Ber. Bunsenges. physik. Chem., 81, 645 (1977).

12) K. E. Heusler \& K. Schoner: Ber. Bunsenges. physik. Chem., 77, 885 (1973).

13) A. G. Akimov, I. L. Rozenfel'd \& M. G. Astaf'ev: Zashch. Met., 12, 167 (1976).

14) A. G. Akimov, M. G. Astaf'ev \& I. L. Rozenfel'd: Zashch. Met., 12, 321 (1976).

15) J. D. E. McIntyre: "Advances in Electrochemistry and Electrochemical Engineering," Vol. 9, Ed. by P. Delahay \& C. W. Tobias, p. 61, Jhon Wiley \& Sons, New York (1973).

16) W. J. Anderson \& W. N. Hansen: J. Electroanal. Chem., 47, 229 (1973).

17）原 信義, 杉本克久: J. Electrochem. Soc. 誌汇 投稿中

18) O. G. Holmes \& D. S. McClure: J. Chem. Phys., 26, 1686 (1957).

19) P. C. Bailey: J. Appl. Phys., 31, 39S (1960).

20) K. A. Wickershein \& R. A. Lefever: J. Chem. Phys., 36, 844 (1962).

21) U.Stimming \& J. W. Schultze: Ber. Bunsenges. physik. Chem., 80, 1297 (1976).

22) 青木昌治, 福家俊郎: 応用物理, 36, 422 (1967).

23) H. H. Tippins: Phys. Rev., B1, 126 (1970).

24) D. S. McClure: J. Chem. Phys., 36, 2757 (1962).

25) G. Kortum: Z. physik. Chem., 33, 243 (1936).

26) G. Bouyssoux, M. Romand, H. D. Polaschegg \& J. T. Calow: J. Electron Spectrosc. Relat. Phenom., 11, 185 (1977).

27) R. Newman \& R. M. Chrenko: Phys. Rev., 114, 1507 (1959).

28) R. J. Powell \& W. E. Spicer: Phys. Rev., B2, 2182 (1970).

29) 八巻孝男: 東北大学学士卒業論文（昭和 53 年 3 月) p. 43 .

30) K. Sugimoto \& Y. Sawada: Proc. 5th Int. Cong. Metallic Corrosion, p. 290, Tokyo (1972).

31) K. Sugimoto \& Y. Sawada: Boshoku Gijutsu, 23, 63 (1974).

32) K. Sugimoto \& Y. Sawada: Corros. Sci., 17, 425 (1977).

33）杉本克久, 岸 興作, 池田重良, 沢田可信：日 本金属学会誌, 38, 54 (1974). 